\title{
Students as Co-Inquirers in Australian Higher Education: Opportunities and Challenges
}

Followed by Student Response by Matthew Teal

\begin{abstract}
While the model of students and staff working in partnership to enhance university education is well-established internationally, it is still an emerging field in Australia where most of such initiatives involve only small numbers of students. This paper examines the opportunities and challenges for students-as-co-inquirers initiatives in Australia. Drawing on a review of the literature, a consideration of theory, and discussions with colleagues, I propose ways in which students as co-inquirers practice and research might move forward, both in Australia and globally.
\end{abstract}

\section{KEYWORDS}

students as partners, students as change agents, student researchers, innovative pedagogies

One of the most significant aspects of co-inquiring with students [is] the ability to make meaning of student experience through the eyes of students themselves.

Thursari Welikala \& Chris Atkin, "Student Co-Inquirers: the Challenges and Benefits of Inclusive Research"

\footnotetext{
"Students as co-inquirers," as noted by Verwoord (2014), is "a growing movement within higher education that recognizes the importance of involving students as contributors to all aspects of teaching and learning including research activities within the scholarship of teaching and learning." Students-as-co-inquirers initiatives are well established elsewhere, such as the UK (e.g., Higher Education Academy, 2014), the USA (e.g., Cook-Sather, 2014a) and as shown in the growing emphasis of the International Society for the Scholarship of Teaching and Learning (ISSoTL) on student involvement in conferences and on committees (Verwoord, 2014). Indeed, ISSoTL's Students as Co-Inquirers Special Interest Group was founded as one of the first ISSoTL SIGs (Werder, 2014).

Further testimony to this growing movement can be found in four recent publications (Cook-Sather, Bovill, \& Felten, 2014; Dunne \& Owen, 2013; Healey, Flint, \& Harrington, 2014; Little, 2011), serving as excellent guides through the students-as-co-inquirers' terrain. And there are of course many examples of such initiatives in this special section.

Ramsden believes that we "will not be able to take the student experience forward unless we see it as a joint venture between students and those who provide higher education" (2008, p. 1$)$. This belief is shared by many working in higher education who have found that students as co-inquirers initiatives have had successful outcomes for students, staff, and universities.

While the Australian higher education sector has led the way in gathering data about students' learning experiences and listening to the 'student voice' (e.g., Griffin, Coates, McInnis, \& James, 2003) and many Australian universities have pursued programs designed to foster student
} 
engagement (e.g., Kift, 2015), very few have capitalised on university-wide strategies informed by the international movement about students as co-inquirers. Where nascent students-as-partners' initiatives exist in Australia, they tend to involve only relatively small numbers of students on a project or program level, rather than the level of organisational strategy where arrangements for genuine partnership between academics and students are embedded in institutional structures and practices.

This paper examines why the model of students and staff partnering to co-inquire about teaching and learning is still an emerging field in Australia. I present an analysis of the literature and a discussion about how theory might inform the field, interwoven with excerpts of interviews with colleagues, ${ }^{1}$ which further illuminate the barriers to and attitudes towards such initiatives in Australia in particular. I then propose some suggestions about how Australian institutions might further engage in students-as-co-inquirers practice and several areas for further research.

In her introduction to the book Opening Lines, Pat Hutchings describes a type of Scholarship of Teaching and Learning question that calls for "formulating a new conceptual framework" - what she calls a "vision of the possible" (2000, p. 5). In this paper, I work with theory and practical examples to explore why it is hard to develop a culture of co-inquiry with students. In envisioning what might be possible, this piece has the potential to help institutions and individuals better understand what is needed to build a culture of co-inquiry with students, in Australia and elsewhere.

\section{BENEFITS AND BARRIERS TO STUDENTS-AS-CO-INQUIRERS INITIATIVES}

Undertaking students-as-co-inquirers initiatives for universities, students, and academics has many potential benefits. Students-as-co-inquirers initiatives have influenced policy and practice (Dunne \& Zandstra, 2011), including curriculum renewal (Delpish, Darby, Holmes, KnightMcKenna, Mihans, Kind, \& Felten, 2010). Students co-inquiring with academics become more involved in their learning (Werder, Ware, Thomas, \& Skogsberg, 2010); feel appreciated (Delpish et al., 2010); gain graduate attributes that maximise their employability (Dunne \& Zandstra, 2011; Bovill, Cook-Sather, Felten, Millard, \& Moore-Cherry, 2015); develop confidence, leadership, and decision-making skills (Welikala \& Atkin, 2014); and can express their learning in different ways (Delpish et al., 2010). Students also experience greater group cohesion, high levels of self-directed learning, increased confidence and motivation, and improved performance (Bovill, 2014, p. 21), including improved marks, pass rates, and attendance (Brooman, Darwent, \& Pimor, 2015). Students also develop deeper self-awareness (Cook-Sather, 2014b) and greater meta-cognitive awareness (Bovill et al., 2015).

Academics co-inquiring with students feel more inspired about their teaching (Werder et al., 2010), realise the value of students' views (Delpish et al., 2010; Cook-Sather, 2014b), experience transformed views about teaching (Bovill, 2014; Cook-Sather, 2014a) and gain deeper selfawareness (Cook-Sather, 2014b).

In summary, both students' and academics' views about learning and teaching are transformed. While the evidence is clear, the next challenge is to ensure that students-as-partners initiatives are embedded in the institutional structures and arrangements of Australian universities. An important aspect of meeting this challenge involves considering the barriers to students-as-coinquirers initiatives.

The systems in the way they're set up reify the continuation of that model [where academics have the power] particularly at our university, which is the teacher-expert, studentapprentice type of model. That is really hard to change, and I think there are areas where it really ought to change, especially in research training areas and for honours and $P h D$ 
students. I think it's different between the sciences and the non-sciences. I think the nonsciences are probably still the worst at that apprentice model, but I think it can shift, and people can work on that dynamic. (excerpt from interview with academic)

Universities are places that are not usually open to rapid change and innovation. Students-asco-inquirer initiatives often run counter to "institutional structures, practices and norms" (Bovill et al., 2015, p. 7) and are seen as an unnecessary complication rather than an opportunity. Students are often seen as customers / consumers (e.g., Kleinman \& Osley-Thomas, 2016), so viewing students as people, and caring about their holistic development, "challenges the current dominant discourse of higher education' (Quinlan, 2014, p. 33).

While I sometimes hear academics say things that indicate they do not always view students as people, I also wonder whether students view academics as people. Reflections from student ambassadors in Peseta, Bell, Clifford, English, Janarthana, Jones, Teal, \& Zhang (2016) indicate that many students do not "have an understanding of what academics and universities actually do, how academics organise their time... [and] that many academics want to do more for students, yet ... are limited by time" (p. 60). Other evidence includes this excerpt from a student's letter to my university's student newspaper: "I can't remember ever treating my tutors with actual contempt when I was an undergrad, but I certainly didn't think of them as ACTUAL HUMAN BEINGS with lives and work of their own" (Anonymous, 2015, original emphasis). There is a two-way responsibility: for students to get more involved in their education, and for academics to see students as individuals worthy of respect. Both sides need to have a curiosity about the other. As Peseta et al. state: "Without giving students better clues about the realities of academic life, we limit their capacity to develop, invest, and participate in the very idea of the University itself" (2016, p. 64).

Academics hold positions of power, and they may be reluctant to share that power with students. Some forms of students-as-co-inquirers initiatives are possibly more threatening to academics than others. For example, students being trained as consultants to give feedback on academics' teaching (Cook-Sather, 2014a) is a somewhat radical redefinition of the role of student, and some academics may not relish relinquishing their role as the expert: "opening up these [teaching] processes to review can be perceived as entailing considerable personal and professional risk" (Bovill et al., 2015, pp. 4-5). A further challenge is that it may be difficult for academics to fully involve students as genuine co-researchers (Welikala \& Atkin, 2014; Allin, 2014). Students-as-coinquirers initiatives may also create anxiety about the unknown for students (Bovill et al., 2015) because when students become co-inquirers, their role changes and becomes more fluid.

Some students are desperate to effect change but are invited into the conversation too late and in a tokenistic way. Even students in leadership positions in Australian universities (446 were surveyed) do not "identif[y] their role as directly influencing teaching and learning or having an impact on curriculum" (Deane \& Stanley, 2015, 133). Carey (2013) found that students involved in curriculum design sometimes encountered hostility or apathy from academics and were aware that their comments in meetings might impact their marks. Students experienced the ratio of staff to students in curriculum design meetings as too high and the language as sometimes alienating (Carey, 2013). Clearly there is room to involve students in ways that are more student-friendly.

\section{THEORETICAL CONTRIBUTIONS TO STUDENTS-AS-CO-INQUIRERS PRACTICE AND RESEARCH}

In this special section, several papers provide useful ways of conceptualising students as coinquirers, including the partnering model presented by Healey, Flint, \& Harrigan, and the institutional level model highlighted by Werder, Thibou, Legg, Simkins, Hornsby, \& Franklin; CookSather \& Abbot's notion of translation; and the concept mapping technique and 'cautionary note' 
discussed by Howson \& Weller. Despite these advances in theorising students as co-inquirers, Taylor and Robinson's (2009) assertion that the field is under-theorised still holds. They contend that "student voice has been seen principally as a mode of practical intervention ... allied to agendas around ... improvement" (pp. 161-3). Academics' "own ability to free themselves to struggle against oppressive and dis-abling systems is rather too unproblematically assumed" (p. 167). Taylor and Robinson (2009) see utility "for student voice in taking up postmodernist formulations of power," which they see as "useful for understanding the student voice project as itself unpredictable, as an always unfinished enterprise... always a process of constant revision and re-making” and the "processes of power as situated, endlessly negotiated and (re) constructed, and at the same time, as open to contestation and change" (pp. 169-70).

For some academics, the fact that students as co-inquirers has its roots in "humanist/progressivist philosophies and radical pedagogy" (Taylor \& Robinson, 2009, p. 164) might be off-putting. After all, academics hold a wide range of philosophical and epistemic views, which in turn influence their teaching and the types of learning activities and interventions that they are likely to implement (Keesing-Styles, Nash, \& Ayres, 2014).

Turning to the model by Healey, Flint and Harrington in this issue I find it provokes questions such as: what is the relative importance of the four areas of co-inquiry with students (learning, teaching \& assessment; curriculum design \& pedagogic consultancy; subject-based research \& inquiry; SoTL)? Is it important for students to be co-inquirers into teaching and learning, or it is more beneficial for their learning to focus on the subject-based initiatives? The model does not display visually the contextual factors which impact the success or uptake of the partnership initiatives. Considering other higher education theories, such as student approaches to learning and teacher approaches to teaching, can usefully enrich our understanding of the model presented by Healey and colleagues. For example, research suggests that academics with an Information Transmission Teacher Focussed approach to teaching will be unlikely to want to adopt students-asco-inquirers initiatives, or if they do, will do so only superficially (Prosser \& Trigwell, 1999), as academics with this approach are primarily concerned with transmitting content.

While Healey and colleagues' model offers a useful conceptual resource to think with and against, an alternative lens is provided by the growing scholarship on threshold concepts. Werder and colleagues (2012) and Cook-Sather (2014b) have both argued that academics and students partnering to explore pedagogical practice is a threshold concept, and that such partnerships are "troublesome, transformative, irreversible ... integrative" (Cook-Sather, 2014b, p. 187) and "discursive" (Werder et al., 2012, p. 34). Cook-Sather and Luz (2015) found that once academics cross the threshold, they are "much more likely to think about their work with students less as 'transmission' and as 'more of a transaction'” (p. 1099). Linking the substantial body of work about threshold concepts and academic professional development

(http://www.ee.ucl.ac.uk/ mflanaga/thresholdsA.html) with students as co-inquirers would help us better understand some of the difficulties that academics encounter in the liminal space of partnering with students.

New schemes might also look to the principles and practices of deliberative democracy as a way of involving more students. Deliberative democracy involves inclusion of beliefs and priorities, analysis of information, acknowledging the value of multiple perspectives and consideration of the various and sometimes competing concerns of all stakeholders (Doherty, 2008). Successful student partnership initiatives that have used the framework of deliberative democracy include those by Harriger \& McMillan (2008), Doherty (2008), O’Neill and McMahon (2012), and Bell et al. (2013). The strength of these particular initiatives is that student participation is built into the existing curriculum structures in order to improve learning and teaching. 
There are also other interesting perspectives to explore. The literature about research and engagement in indigenous communities (e.g., Chilisa, 2012; Smith, 1999) can provide valuable insights into the dynamics of partnership. In particular, attention to the values of reflexivity, reciprocity, respect and equality may prove fruitful (Martin, 2008; National Health and Medical Research Council, 2003). Indigenous and post-colonial theorists draw our attention to the voices on the periphery and invite us to challenge the status quo (e.g., Connell, 2007; Gale, 2012)—echoing calls by SoTL practitioners to include a diverse range of students in co-inquiry initiatives (Felten et al., 2013; Cook-Sather \& Agu, 2013).

I have discussed a range of possible theories which might usefully enrich our understanding of student-as-co-inquirers initiatives. Individual scholars will of course utilise the theories which resonate with them, but hopefully this discussion contributes to the necessary yet neglected work of theorising students as co-inquirers. Enabling the field to make broader connections to rich areas for exploration will illuminate students as co-inquirers work in different ways.

I now turn to the Australian context, where nascent students-as-co-inquirers initiatives are ripe for being scaled up and embedded into institutional practices.

\section{THE AUSTRALIAN CONTEXT}

The barriers discussed earlier have not significantly hindered the success of students-as-coinquirers initiatives elsewhere. Is there something about the Australian context of higher education that is particularly unfriendly to such initiatives? In Australia, there are 37 public universities, with over 1 million enrolled students and over 100,000 staff (Universities Australia, 2015). Australian universities have experienced many of the same changes as elsewhere-massification, the rise of eLearning, funding cuts, and a shift to a more corporate style of management (Forsyth, 2014).

However, there are some clear differences, particularly compared to the UK and USA. In the UK, "market-driven policies have placed the student at the heart of the education system...p policies and practices have led to a proliferation of research ... on different aspects of the student experience" (Welikala \& Atkin, 2014, p. 391). Individual institutions, the Higher Education Academy, and the National Union of Students have for some time been working in the students-as-partners space (e.g., Higher Education Academy, 2014). One well-known example is the 'student as producer' project at the University of Lincoln. Scotland has the highly regarded sparqs (student partnerships in quality Scotland), "a publicly funded agency for Scotland's university and college sectors which aims to support student engagement in the quality of the learning experience." In the United States, the small liberal arts college environment where many co-inquirer initiatives have flourished likely encourages a sense of community on campus that is not found in Australia, where many institutions are very large and most students live off-campus.

In Australia, the national funding body for tertiary education innovation, the Office for Learning and Teaching (OLT), has only recently turned its attention to students-as-co-inquirers initiatives. In 2015, the OLT funded a Fellowship on students as partners and is in 2016 embarking on a national Transforming Practice Programme focussed on students as partners. Other Australian examples include Peer Assisted Study Schemes and peer mentoring programs (e.g., O’Shea, 2012), student-organised entrepreneurship, and the Australian Council of Undergraduate Research (ACUR), which hosts an annual conference for undergraduate researchers to present their findings. Student peer mentoring programs are particularly prevalent and involve student mentors working in partnership with university staff to deliver and improve peer mentoring programs, for example:

We try to get student feedback and try to ensure that they have some choice on the direction and changes that happen with the mentoring program, which we're always trying to improve. The mentoring program is students helping students, so they are very much part of deciding 
what's included in training and in the program, and their feedback and suggestions inform what we do. (extract from interview with professional staff member)

There are also examples of discipline-based students-as-co-inquirers initiatives, as a colleague notes below:

We do an activity where the students come up with their own research question, then design a study, collect the data and report it in a scientific paper format. We model the research process, similar to when you submit a paper to a journal, so they submit to an online system for blind peer review. They then get a chance to modify the paper, address the criticisms and submit a final paper. That kind of process has students involved throughout, from coming up with their own ideas, to creating their own assessment activity, and also providing feedback to peers... The students really enjoy designing their own research study. (extract from interview with academic)

While laudable, I contend that many of the examples above are not institution-wide and involve only relatively small numbers of students, and many of the opportunities are taken up by students who are already highly engaged in their studies. For example, a scheme at my own institution involving students working as ambassadors for the annual teaching conference has only involved six students each year (Peseta at al., 2016). Clearly the time has come for Australian universities to consider how students as co-inquirers work can be scaled up, broadened in scope, and made part of institutional policies and practices. The next section explores how this might be done.

\section{WAYS TO MOVE FORWARD}

I think I could make time in the course if I really thought about it. It would help if someone had a template on how to go about doing it in an effective way, rather than coming up with it myself.

\section{Excerpt from Interview with Academic}

One way to encourage Australian institutions to take up this work could be to emphasise the success of institution-wide schemes such those described by Bovill and colleagues (2015) and Werder and colleagues in this special section, and to look at enduring programs like Bryn Mawr College's SaLT (Students as Learners and Teachers) program which has been running since 2006 (Cook-Sather \& Luz, 2015). These and other previous successful initiatives offer several practical suggestions on how to proceed, including:

- Provide institutional funding (Cook-Sather, 2014a)

- Offer the support and championing of academic developers and senior managers (CookSather, 2014a)

- Work with the whole cohort of students, or if this is not possible, make the selection criteria transparent (Bovill et al., 2015)

- Provide practical examples and templates

- Start small and experiment (Bovill, 2014) —examples of ways to start include a co-developed assignment, learning outcome or grading rubric (Cook-Sather, 2014a; Bovill et al. 2015), focus groups about student feedback (Brooman et al., 2015) or World café style deliberations (Bell et al., 2013)

- Ensure good communication and respect (Bovill et al., 2015; Cook-Sather \& Luz, 2015) 
- Allow time for shifts to occur (Cook-Sather, 2014a), while also keeping in mind that a "one off" initiative can have sustained benefits (Brooman et al., 2015),

- Explore the possibilities of technology

I think a generational change in academics will make a difference, and I think technology will enable it as well. Because technology gives easy access to information and communication, and that has a horizontalising effect, and maybe that will change things. I use Facebook groups mainly in my Masters teaching, and that's a really levelling experience. We're all collecting information and data in the same way to contribute to the group and I don't moderate it. (excerpt from interview with academic)

\section{FURTHER QUESTIONS TO EXPLORE}

This piece has considered the Australian experience through the lens of literature mostly situated in the developed (and Western) world. For example, Hoon and Looker (2013) contend that Asian participants and perspectives have been excluded from the SoTL discourse. It is important to discover what students-as-co-inquirers initiatives are taking place in universities in developing and non-Western countries as we imagine these visions for the possible.

Further research is needed on the ways academics' conceptions of and approaches to teaching interact with how and whether they adopt students as co-inquirers initiatives. So far the literature has mostly focussed on successful initiatives where the academics are keen and likely take what Prosser and Trigwell (1999) call a Conceptual Change Student Focussed approach to teaching. Also, what might students themselves tell us more directly about the characteristics of the programs and of their faculty/staff colleagues that make for successful co-inquiry initiatives? What are the benefits of SoTL and curriculum design for students? Is it best to focus efforts in subject-based research and inquiry? There are some examples where initiatives are both subject-based and involve curriculum design (for example, Bovill and colleagues [2015] describe postgraduate students designing a project for undergraduate students) — are such initiatives more powerful than those which only cover one type of co-inquiry? These, and many other questions, await exploration.

Many academics and institutions in Australia still need to be convinced of the benefits of students-as-co-inquirers initiatives. In outlining the opportunities and challenges, in demonstrating how theory might usefully enhance students as co-inquirers in practice, and in presenting some suggestions for practice and research, this paper hopes to assist all involved in higher education to understand better what it takes to promote students as co-inquirers.

\section{ACKNOWLEDGEMENTS}

Thanks to all interviewees, to Carmen Werder, Rebecca Pope-Ruark, Roselynn Verwoord, Karen Hornsby, and Shevell Thibou for their helpful feedback; to Mick Healey for a long ago email conversation that helped shape the paper; and to colleagues in the ITL for useful discussions.

Amani Bell is a Senior Lecturer in the Educational Innovation team at the University of Sydney. Amani's research focuses on building the teaching capacity of academics and on students as co-inquirers.

\section{NOTE}

1. The interviews were carried out as a pilot for a larger study and were conducted with ethics approval. The four interviewees, working in three Australian universities, were two academics, a professional staff member working in student support, and a former Deputy Vice Chancellor Education. I asked the interviewees about what types of students as co-inquirers initiatives they were aware of and what they thought it might take to promote this kind of co-inquiry. 


\section{REFERENCES}

Allin, L. (2014). Collaboration between staff and students in the scholarship of teaching and learning: The potential and the problems. Teaching \& Learning Inquiry: The ISSOTL Journal, 2(1), 95-102.

A to the editors. Honi Soit, Semester 1, Week 4.

Australian Universities (2015). Groupings of Australian Universities.

Bell, A., Carson, L. \& Piggott, L. (2013). Deliberative democracy for curriculum renewal. In E. Dunne \& D. Owen (Eds.), The student engagement handbook: Practice in higher education (pp. 499-508). Bingley: Emerald.

Bovill, C. (2014). An investigation of co-created curricula within higher education in the UK, Ireland and the USA. Innovations in Education and Teaching International, 51(1), 15-25.

Bovill, C., Cook-Sather, A., Felten, P., Millard, L., \& Moore-Cherry, N (2015). Addressing potential challenges in co-creating learning and teaching: Overcoming resistance, navigating institutional norms and ensuring inclusivity in student-staff partnerships. Higher Education, 1-14.

Brooman, S., Darwent, S., \& Pimor, A. (2015). The student voice in higher education curriculum design: Is there value in listening? Innovations in Education and Teaching International, 52(6), 663-674.

Carey, P. (2013). Student as co-producer in a marketised higher education system: A case study of students' experience of participation in curriculum design. Innovations in Education and Teaching International, 50(3), 250-260.

Chilisa, B. (2012). Indigenous research methodologies. Los Angeles: Sage.

Connell, R. (2007). Southern theory: The global dynamics of knowledge in social science. Allen \& Unwin.

Cook-Sather, A. (2014a). Student-faculty partnership in explorations of pedagogical practice: A threshold concept in academic development. International Journal for Academic Development, 19(3), 186-198.

Cook-Sather, A. (2014b). Multiplying perspectives and improving practice: What can happen when undergraduate students collaborate with college faculty to explore teaching and learning. Instructional Science, 42(1), 31-46.

Cook -Sather, A., \& Agu, P. (2013). Students of color and faculty members working together toward culturally sustaining pedagogy. In Laura Cruz (Ed.), To improve the academy: Resources for faculty, instructional, and organizational development, 32 (pp. 271-285). John Wiley \& Sons.

Cook-Sather, A., \& Luz, A. (2015). Greater engagement in and responsibility for learning: What happens when students cross the threshold of student-faculty partnership. Higher Education Research \& Development, 34(6), 1097-1109.

Cook-Sather, A., Bovill, C., \& Felten, P. (2014). Engaging students as partners in learning and teaching: A guide for faculty. John Wiley \& Sons.

Deane, E. M., \& Stanley, K. (2015). The student leadership in curriculum development and reform project. In T. Thomas, E. Levin, P. Dawson, K. Fraser, \& R. Hadgraft (Eds.), Research and development in higher education: Learning for life and work in a complex world, 38 (pp. 130-140). Melbourne, Australia, 6-9 July 2015.

Delpish, A., Darby, A., Holmes, A., Knight-McKenna, M., Mihans, R., King, C., \& Felten, P. (2010). Student-faculty partnerships in course design. In C. Werder \& M. M. Otis (Eds), Engaging student voices in the study of teaching and learning (pp. 96-114). Virginia: Stylus.

Doherty, J. (2008). Individual and community: Deliberative practices in a first-year seminar. In J. R. Dedrick, L. Grattan, \& H. Dienstfrey (Eds.), Deliberation and the work of higher education (pp. 59-87). Ohio: Kettering Foundation.

Dunne, E. \& Owen, D. (Eds.) (2013). The Student engagement handbook: Practice in higher education. Bingley: Emerald.

Dunne, E., \& Zandstra, R. (2011). Students as change agents-New ways of engaging with learning and teaching in Higher Education. Bristol: A joint University of Exeter ESCalate / Higher Education Academy Publication.

Felten, P., Bagg, J., Bumbry, M., Hill, J., Hornsby, K., Pratt, M., \& Weller, S. (2013). A call for expanding inclusive student engagement in SoTL. Teaching \& Learning Inquiry: The ISSOTL Journal, 1(2), 63-74.

Forsyth, H. (2014). A history of the modern Australian university. New South.

Gale, T. (2012). Towards a southern theory of student equity in Australian higher education: Enlarging the rationale for expansion. International Journal of Sociology of Education, 1(3), 238-262.

Griffin, P., Coates, H., Mcinnis, C., \& James, R. (2003). The development of an extended course experience questionnaire. Quality in Higher Education, 9(3), 259-266. 
Harriger, K. J., \& McMillan, J. J. (2008). Contexts for deliberation: Experimenting with democracy in the classroom, on campus, and in the community. In J. R. Dedrick., L. Grattan, \& H. Dienstfrey (Eds.), Deliberation and the work of higher education (pp. 235-265). Ohio: Kettering Foundation.

Healey, M., Flint, A., \& Harrington, K. (2014). Engagement through partnership: Students as partners in learning and teaching in higher education. York, UK: The Higher Education Academy.

Higher Education Academy (2014). Framework for partnership in learning and teaching in higher education.

Hoon, C. H., \& Looker, P. (2013). On the margins of SoTL discourse: An Asian perspective. Teaching \& Learning Inquiry: The ISSOTL Journal, 1(1), 131-145.

Hutchings, P. (2000). Opening lines: Approaches to the scholarship of teaching and learning. Menlo Park, USA: Carnegie Publications, the Carnegie Foundation for the Advancement of Teaching.

Keesing-Styles, L., Nash, S., \& Ayres, R. (2014). Managing curriculum change and 'ontological uncertainty' in tertiary education. Higher Education Research \& Development, 33(3), 496-509.

Kift, S. (2015). A decade of transition pedagogy: A quantum leap in conceptualising the first year experience. HERDSA Review of Higher Education, 2, 51-86.

Kleinman, D. L., \& Osley-Thomas, R. (2016). Codes of commerce and codes of citizenship: A historical look at students as consumers within US higher education. In Berman, E.P. (Ed), The university under pressure (research in the sociology of organizations, volume 46) (pp. 197-220). Emerald Group Publishing Limited.

Little, S. (Ed.). (2011). Staff-student partnerships in higher education. London, UK: Continuum.

Martin, K. L. (2008). Please knock before you enter: Aboriginal regulation of outsiders and the implications for researchers. Brisbane: Post Pressed.

National Health and Medical Research Council (2003). Values and ethics: Guidelines for ethical conduct in Aboriginal and Torres Strait Islander health research. Canberra: Commonwealth of Australia.

O'Neill, G., \& McMahon, S. (2012). Giving student groups a stronger voice: using participatory research and action (PRA) to initiate change to a curriculum. Innovations in Education and Teaching International, 49 (2), 161-171.

O'Shea, S. (2012). UStart: A peer designed and led orientation activity. E-Source for College Transitions, 9(2), 46.

Peseta, T., Bell, A., Clifford, A. English A., Janarthana, J., Jones, C., Teal, M., \& Zhang, J. (2016). Students as ambassadors and researchers of assessment renewal: Puzzling over the practices of university and academic life. The International Journal for Academic Development 21:1, 54-66.

Prosser, M., \& Trigwell, K. (1999). Understanding learning and teaching. UK: Open University Press.

Quinlan, K. M. (2014). Leadership of teaching for student learning in higher education: What is needed? Higher Education Research \& Development, 33(1), 32-45.

Ramsden, P. (2008). The Future of Higher Education Teaching and the Student Experience.

Smith, L. T. (1999). Decolonizing methodologies: Research and indigenous peoples. Zed books.

Taylor, C., \& Robinson, C. (2009). Student voice: Theorising power and participation. Pedagogy, Culture and Society, 17(2), 167-175.

Universities Australia. (2015). Data snapshot 2014.

Verwoord, R. (2014). ISSoTL and student engagement.

Welikala, T., \& Atkin, C. (2014). Student co-inquirers: The challenges and benefits of inclusive research. International Journal of Research \& Method in Education, 37(4), 390-406.

Werder, C. (2014). Students as co-inquirers: A long history with deep roots.

Werder, C., Thibou, S., \& Kaufer, B. (2012). Students as co-inquirers: A requisite threshold concept in educational development? The Journal of Faculty Development, 26(3), 34-38.

Werder, C., Ware, L., Thomas, C., \& Skogsberg, E. (2010). Students in parlour talk on teaching and learning. In C. Werder \& M. M. Otis (Eds.), Engaging student voices in the study of teaching and learning. (pp. 1631). Virginia: Stylus. 


\section{Student Response to "Students as Co-Inquirers in Australian Higher Education: Opportunities and Challenges"}

As a student who has been involved in co-inquirer initiatives during my studies, I found this paper very helpful in understanding the broader array of challenges involved in such initiatives in other Australian higher education institutions.

Regarding the development of attitudes in students described on page 3 who are engaged in co-inquirer initiatives, I am interested to know if this builds on pre-existing attitudes that may have actually influenced the selection of these students for the role. The inadvertent biases of the selection process are indicated on page 7 , when Bell asserts that "opportunities are probably only taken up by students who are already highly engaged in their studies," and page 10, which lists the need for more transparent selection criteria. Academics may well be attracted to students who are "more involved in their learning" and already demonstrate "confidence, leadership and decision-making skills." Do co-inquirer initiatives show preference to students who are more academically engaged? Is it possible to get involvement from students with different attitudes to extra-curricular initiatives?

Regarding the Office for Teaching and Leaning, I wasn't aware of this before reading this paper. Should students be more aware of it and how could this be facilitated?

It would be interesting to know how many of the 1 million students enrolled in higher education in Australia are also part of the 100,000 staff in such roles as tutors, student-services casuals, and student representatives. These students might be in a good position to increase student engagement with SoTL and curriculum design.

There are broad implications arising from this paper. I would like to see more of my fellow education students engaged in consultation on units of study, especially as they should graduate with many of the attributes necessary to teach effectively in universities. Also, undergraduate research projects such as the one mentioned on pages 6-7 are great initiatives; I am involved in one at the moment. Additionally, researchers could consult international students at institutions such as the University of Sydney to learn from their experiences of co-inquirer initiatives in other countries and to engage them in new initiatives. The important question becomes, "How can universities increase the representation of faculties engaged in this mode of teaching and learning?"

Matthew Teal is an undergraduate student in the Faculty of Education and Social Work at the University of Sydney.

Copyright for the content of articles published in Teaching \& Learning Inquiry resides with the authors, and copyright for the publication layout resides with the journal. These copyright holders have agreed that this article should be available on open access under a Creative Commons Attribution License 4.0 International (https://creativecommons.org/licenses/by/4.0). The only constraint on reproduction and distribution, and the only role for copyright in this domain, should be to give authors control over the integrity of their work and the right to be properly acknowledged and cited, and to cite Teaching \& Learning Inquiry as the original place of publication. Readers are free to share these materials-as long as appropriate credit is given, a link to the license is provided, and any changes are indicated. 